\title{
PROMANCOA Modular Technology for the Valorization of Mango (Mangifera indica L.) and Cocoa (Theobroma cacao L.) Agricultural Biowastes
}

\author{
Alberto J. Núñez-Sellés *, Alejandro J. Abril-González and Marlen Ramil-Mesa \\ Research Divison, Universidad Nacional Evangélica (UNEV), Paseo de los Periodistas 54, Ensanche Miraflores, \\ Santo Domingo CP 10203, Dominican Republic; aabril@prof.unev.edu.do (A.J.A.-G.); \\ mramil@unev.edu.do (M.R.-M.) \\ * Correspondence: anunez@unev.edu.do; Tel.: +1-809-481-6256
}

check for

updates

Citation: Núñez-Sellés, A.J.;

Abril-González, A.J.; Ramil-Mesa, M.

PROMANCOA Modular Technology

for the Valorization of Mango

(Mangifera indica L.) and Cocoa

(Theobroma cacao L.) Agricultural

Biowastes. Processes 2021, 9, 1312.

https://doi.org/10.3390/pr9081312

Academic Editor: Ibrahim

M. Abu-Reidah

Received: 29 June 2021

Accepted: 27 July 2021

Published: 29 July 2021

Publisher's Note: MDPI stays neutral with regard to jurisdictional claims in published maps and institutional affiliations.

Copyright: (C) 2021 by the authors. Licensee MDPI, Basel, Switzerland. This article is an open access article distributed under the terms and conditions of the Creative Commons Attribution (CC BY) license (https:// creativecommons.org/licenses/by/ $4.0 /)$.

\begin{abstract}
PROMANCOA modular technology (PMT) aims at the development of modular agricultural biowaste valorization of mango (Mangifera indica L.) and cocoa (Theobroma cacao L.) cultivars within the concept of circular economy in agriculture management. The modular design includes four modules: (1) green raw material (GRM) selection and collection, (2) GRM processing, (3) GRM extraction, in order to obtain bioactive green extracts (BGE) and bioactive green ingredients (BGI), and (4) quality control, which lead to formula components for food, feed, nutraceutical and/or cosmeceutical products. PMT was applied to mango stem bark and tree branches, and cocoa pod husk and bean shells, from cultivars of mango and cocoa in provinces of the Dominican Republic (DR). PMT might be applied to other agricultural biowastes, where a potential of value-added BGE/BGI may be present. Alongside the market potential of these bioactive ingredients, the reduction of carbon dioxide and methane emissions of agricultural biowastes would be a significant contribution in order to reduce the greenhouse effect of these residuals.
\end{abstract}

Keywords: circular economy; agricultural management; mango; cocoa; nutraceuticals; cosmeceuticals

\section{Introduction}

The goal of circular economy (CE) is the recovery and valorization of waste materials in order to re-use it as value-added products and reduce the environmental impact of wastes by using renewable sources when possible [1]. This technological development is creating new business models and employment opportunities with a positive impact on social development [2]. Several technologies have been developed within the CE concept in order to re-use plastics [3], textiles [4], fruit-industrial by-products [5], and agricultural products [6], among others. The present manuscript describes the development of a modular technology for the utilization of agricultural biowastes from mango (Mangifera indica L.) and cocoa (Theobroma cacao L.) in the Dominican Republic (DR), leading to value-added products for cosmetic, food, and pharma industries named PROMANCOA (products from mango and cocoa).

The DR has large plantations of mango and cocoa, which produce a considerable amount of waste, such as tree branches (mango), during the annual prune period, and pod husks and shells (cocoa), which are produced in two harvest periods (spring and autumn). Mango branch trees (MBT) and cocoa pod husks (CPH) are usually left in the field as organic matter to the soil, while cocoa bean shells (CBS) might be incinerated or used as a food additive. Previous research has demonstrated that mango stem bark (MSB) can be collected, without affecting the tree phytosanitary condition, having attractive antioxidant and anti-inflammatory properties, which may lead to several innovative food, cosmetic, and pharmaceutical formulations [7]. The antioxidant effect of cocoa is one of the main advantages for the consumers, and it is the major claim of chocolate producers [8]. 
Mangoes are cultivated in the DR along more than 3000 ha from 58 different varieties. Trees are pruned annually in the autumn season (September to October) and this waste is left in the field. Moreover, the stem bark may be collected from mango trees all year long, and this collection may be repeated on the same tree every 3-4 years [9]. It was estimated that more than 1500 tons of MBT are left in the field, and around 300 tons of MSB may be collected annually. These bioproducts have a large content of antioxidant flavonoids and xanthones. Phenolic compounds are highly abundant bioactive compounds in natural products, and more than 8000 structures were reported, from low-molecular weight single phenols to high-molecular weight oligomeric substances, such as tannins [10]. Flavonoids and xanthones are polyphenols, which have been targeted by many researchers due to their biological activities, mainly related to its antioxidant mechanism of action [11,12], and its presence was reported in mango [13], and cocoa [14] extracts. Therefore, if these green raw materials (GRM) are processed, leading to standardized natural products with a defined content of flavonoids and xanthones, it may lead to new bioactive green ingredients (BGI), which might be used in food, cosmetic, and pharmaceutical formulations as antioxidants or food supplements. The annual productive potential of mango-derived antioxidant BGI in the DR is an estimated 15 tons and 3 tons from MBT and MSB, respectively. Within the mango BGI, mangiferin, 2- $\beta$-D-glucopyranosyl-1,3,6,7-tetrahydroxy-9H-xanthen-9-one (MF), is the main component in the polyphenol fraction, and it has been studied extensively, both pre-clinical and clinical, as one of the most promising candidates to be developed as cosmeceutical, nutraceutical or pharmaceutical products [15].

Cocoa is cultivated in the DR along 173,000 ha from different varieties, representing $12 \%$ of the country's forests. Cocoa seed production in the DR (2018 and 2019) was around 80,000 tons, and $20 \%$ of it was produced according to international procedures of organic production [16]. Dominican cocoa, both conventional and organic, is well positioned in the world market (with $60 \%$ of the organic cocoa market, and the second country exporter of fine cocoa). Therefore, new products derived from Dominican cocoa would have a recognized position within the food and cosmetic markets. The main problem from cocoa production is the high amount of $\mathrm{CPH}$ residues that are left in the field, generally in the order of 10 tons per each ton of cocoa seeds. This means that more than 100,000 tons of $\mathrm{CPH}$ are left out in cocoa fields every year, leading to a considerable environmental impact in terms of greenhouse gases emissions. This problem can not be solved with the current uses for this waste, such as compost and animal feed, because the demand would not meet the supply.

CBS is the film that covers the cocoa seed and it is an industrial residue in the processing of cocoa. This material represents between $7 \%$ and $15 \%$ of the cocoa seeds [17]. It was reported that artisanal infusions of CBS have important antioxidant activity [18]. Applications of CBS on animal feed of different types, foodstuff, agriculture, biofuels, and others were reported in a review [19]. Other authors have reported the presence of oligomeric proanthocyanidins (OPA) in cocoa and CBS [20,21].

We present a technology for processing CBS in order to produce a standardized OPA-rich antioxidant BGI, with around $10 \%$ yield (dry mass) and the potential to produce 8000 tons/year of CBS-BGI from 80,000 tons of cocoa beans. Currently, there is a lack of industrial capacity in the DR to process mango and cocoa agricultural residues. Technological development results presented in this manuscript foster the rational basis for investments in such industry. Consumers would benefit from having new natural antioxidant formulations of higher efficacy than current commercially available products, farmers would benefit from selling agricultural biowastes to the industrial producers and, thus, increasing their incomes, and the environment would benefit from the decreased greenhouse gas emissions to the atmosphere. 


\section{Results}

\subsection{Collection of Green Raw Material (GRM)}

\subsubsection{Mango}

Three farms were selected for mango GRM collection in Baní, Azua, and Puerto Plata, DR (Table 1). Collected MSB were around three tons (one ton from Puerto Plata and two tons from Baní) and MBT around three tons (one ton from Azua and two tons from Baní) from Haden and Tommy Atkins varieties, respectively. Standardized operational procedures (SOP) concerning GRM collection from mango farms were filled in the UNEV Quality Assessment Department [22,23].

Table 1. Selection of farms for collecting mango green raw material.

\begin{tabular}{cccccc}
\hline \multirow{2}{*}{ Farm } & \multirow{2}{*}{ Location } & Varieties & No. Plants & \multicolumn{2}{c}{ Potential of GRM (ton) } \\
\cline { 3 - 6 } Mangos Ecológicos & \multirow{2}{*}{ Matanzas, Bani } & Haden & 360 & MSB & MBT \\
\cline { 3 - 6 } & & T. Atkins & 810 & - & 20 \\
\hline Finca Espaillat & C. Altamira, P. Plata & T. Atkins & 120 & - \\
\hline Finca Rodriguez & Azua & Haden & 60 & - \\
\hline
\end{tabular}

Legend: GRM: green raw material; MSB: mango stem bark; MBT: mango branch tree.

\subsubsection{Cocoa}

Two farms were selected for cocoa GRM collection in Villa Altagracia and San Francisco de Macoris, DR (Table 2). The collected CPH were around four tons (three tons from green-yellowish and one ton from red-orange pods) and $810 \mathrm{~kg}$ of CBS (630 kg from green-yellowish pods and $180 \mathrm{~kg}$ from red-orange pods). SOP about GRM collection from CPH was filled in the UNEV Quality Assessment Department [24]. CBS were collected at the cocoa factory directly, without an SOP, but considered the variety origin. Although the difference between green-yellowish and red-orange pod husks has not been relevant for the cocoa industry, we assumed that such color difference might influence the antioxidant activity of subsequent cocoa extracts.

Table 2. Selection of farms for collecting cocoa green raw material.

\begin{tabular}{|c|c|c|c|c|c|}
\hline \multirow{2}{*}{ Farm } & \multirow{2}{*}{ Location } & \multirow{2}{*}{ Varieties } & \multirow{2}{*}{ No. Plants } & \multicolumn{2}{|c|}{ Potential of GRM (kg) } \\
\hline & & & & $\mathrm{CPH}$ & CBS \\
\hline \multirow{2}{*}{ El Maizal } & \multirow{2}{*}{ Villa Altagracia } & Hybrid-Green & 82 & 1640 & 360 \\
\hline & & Hybrid-Red & 16 & 320 & 80 \\
\hline \multirow{2}{*}{ El Ramonal } & \multirow{2}{*}{ San Francisco de Macorís } & Hybrid-Green & 112 & 2240 & 560 \\
\hline & & Hybrid-Red & 32 & 640 & 160 \\
\hline
\end{tabular}

Legend: GRM: green raw material; CPH: cocoa pod husk; CBS: cocoa bean shell.

\subsection{GRM Processing}

2.2.1. GRM Drying

- Mango: The GRM water content from MSB was reduced from $42.7 \%$ to $11.8 \%$ with solar drying, and from $11.8 \%$ to $5.8 \%$ with rotary hot air drying according to results shown in Table 3. The MSB from Baní had a significantly higher water content than the one from Puerto Plata, which corroborated the importance of geographical origin for the GRM yield. However, GRM from both origins had similar water content after the drying operation units, which allowed for the subsequent standardization of the following bioactive green extract (BGE) extraction. MBT, which was allowed to solar dry in the field for a number of weeks, was directly submitted to hot air drying due to its low water content (around 10\%). MBT yields were considerably higher compared 
to MSB, as shown in Table 4. A significant lower yield of MSB was obtained in the Baní farm as compared to the Puerto Plata farm;

- Cocoa: The CPH water content was reduced from an average of $84.5 \%$ to $14.6 \%$ after solar drying, and from $14.6 \%$ to $5.5 \%$ after rotary hot air drying, as shown in Table 5. No significant differences were observed between both geographical origins and between different colored pods. The GRM from all origins and varieties had a similar water content for subsequent extraction. The average yield of dried $\mathrm{CPH}$ was around $6 \%$.

\subsubsection{GRM Milling and Pelletizing}

The physical characterization of GRM pellets for both mango and cocoa are shown in Table 6. It was not necessary to use binders to achieve the consolidation of the pellets, because of the presence of lignin as a natural binder in the GRM, which contributed to the consolidation of the pellets under our experimental conditions. Figure 1 shows photos of the pellets obtained from each GRM.

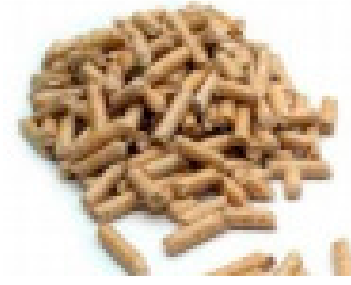

(1)

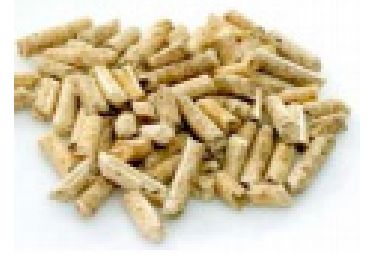

(3)

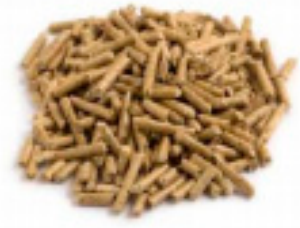

(2)

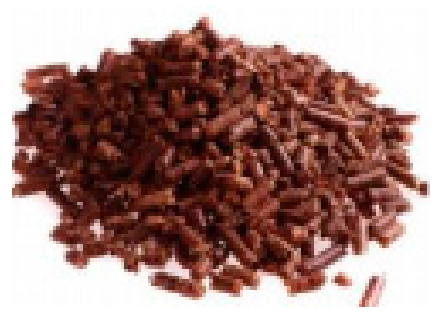

(4)

Figure 1. Pellets from mango and cocoa agricultural biowastes: (1) mango stem bark, (2) mango branch tree, (3) cocoa pod husk, (4) cocoa bean shell.

Table 3. Yield of mango stem bark and water content after drying.

\begin{tabular}{|c|c|c|c|c|c|c|c|}
\hline \multirow{2}{*}{ Farm } & \multirow{2}{*}{ Batch } & \multicolumn{3}{|c|}{ MSB (kg) } & \multirow{2}{*}{$\begin{array}{l}\text { Final Water } \\
\text { Content }(\%)\end{array}$} & \multicolumn{2}{|c|}{ Yield (\%) } \\
\hline & & Field & Solar & Hot Air & & Solar & Hot Air \\
\hline \multirow{4}{*}{ P. Plata } & SBTA01 & 362 & 211.5 & 200.1 & 5.8 & 58.4 & 55.3 \\
\hline & SBTA02 & 396 & 314.2 & 298.5 & 4.9 & 79.3 & 75.3 \\
\hline & SBTA03 & 311 & 208.0 & 198.0 & 5.4 & 66.9 & 63.7 \\
\hline & \multicolumn{4}{|c|}{ Mean value $\pm S D$} & $5.4 \pm 0.4$ & $68.2 \pm 5.5$ & $64.8 \pm 6.9$ \\
\hline \multirow{4}{*}{ Baní } & SBH01 & 532 & 236.5 & 222.2 & 6.2 & 44.4 & 41.8 \\
\hline & SBH02 & 686 & 424.0 & 390.0 & 5.3 & 61.8 & 56.9 \\
\hline & SBH03 & 885 & 561.3 & 354.4 & 5.5 & 63.4 & 40.0 \\
\hline & \multicolumn{4}{|c|}{ Mean value \pm SD } & $5.7 \pm 0.5$ & $56.5 \pm 7.1$ & $46.2 \pm 8.8$ \\
\hline
\end{tabular}

Legend: MSB: mango stem bark; SBTA: stem bark Tommy Atkins; SBH: stem bark Haden; SD: standard deviation. No significant differences were observed between geographical origins. 
Table 4. Yield of mango branch tree and water content after drying.

\begin{tabular}{|c|c|c|c|c|c|c|c|}
\hline \multirow{2}{*}{ Farm } & \multirow{2}{*}{ Batch } & \multicolumn{3}{|c|}{ MBT (kg) } & \multirow{2}{*}{$\begin{array}{c}\text { Water } \\
\text { Content (\%) }\end{array}$} & \multicolumn{2}{|c|}{ Yield (\%) } \\
\hline & & Field & Solar & Hot Air & & Solar & Hot Air \\
\hline \multirow{4}{*}{ Azua } & ВТH01 & 288 & - & 270.1 & 4.9 & - & 93.8 \\
\hline & ВТН02 & 365 & - & 340.0 & 5.4 & - & 93.1 \\
\hline & ВТH03 & 430 & - & 400.6 & 5.8 & - & 93.2 \\
\hline & \multicolumn{4}{|c|}{ Mean value \pm SD } & $5.5 \pm 0.4$ & & $93.4 \pm 0.4$ \\
\hline \multirow{4}{*}{ Baní } & BTTA01 & 445 & - & 429.5 & 7.8 & - & 96.5 \\
\hline & BTTA02 & 670 & - & 650.0 & 7.5 & - & 97.1 \\
\hline & BTTA03 & 895 & - & 822.3 & 5.6 & - & 91.8 \\
\hline & \multicolumn{4}{|c|}{ Mean value \pm SD } & $6.9 \pm 1.0$ & - & $95.1 \pm 2.8$ \\
\hline
\end{tabular}

Legend: MBT: mango branch tree; BTH: branch tree Haden; BTTA: branch tree Tommy Atkins; SD: standard deviation. No significant differences were observed between geographical origins.

Table 5. Yield of cocoa pod husk and water content after drying.

\begin{tabular}{|c|c|c|c|c|c|c|c|}
\hline \multirow{2}{*}{ Farm } & \multirow{2}{*}{ Batch } & \multicolumn{3}{|c|}{ CPH Weight (kg) } & \multirow{2}{*}{$\begin{array}{c}\text { Water } \\
\text { Content }(\%)\end{array}$} & \multicolumn{2}{|c|}{ Yield (\%) } \\
\hline & & Field & Solar & Hot Air & & Solar & Hot Air \\
\hline \multirow{8}{*}{ El Maizal } & GreenM1 & 400 & 64.4 & 22.5 & 4.8 & 16.1 & 5.6 \\
\hline & GreenM2 & 200 & 26.8 & 11.5 & 7.2 & 13.4 & 5.8 \\
\hline & GreenM3 & 200 & 31.9 & 12.0 & 6.5 & 15.6 & 6.0 \\
\hline & \multicolumn{4}{|c|}{ Mean value \pm SD } & $6.2 \pm 1.0$ & $15.2 \pm 0.8$ & $5.8 \pm 0.2$ \\
\hline & RedM1 & 200 & 27.7 & 10.1 & 5.5 & 13.9 & 5.1 \\
\hline & RedM2 & 200 & 25.2 & 11.0 & 6.0 & 12.6 & 5.5 \\
\hline & RedM3 & 200 & 30.0 & 12.5 & 7.1 & 15.0 & 6.3 \\
\hline & \multicolumn{4}{|c|}{ Mean value \pm SD } & $6.3 \pm 0.6$ & $13.8 \pm 1.1$ & $5.6 \pm 0.7$ \\
\hline \multirow{8}{*}{ El Ramonal } & GreenR1 & 400 & 67.5 & 19.6 & 5.2 & 16.9 & 4.9 \\
\hline & GreenR2 & 400 & 59.8 & 18.0 & 5.0 & 15.0 & 4.5 \\
\hline & GreenR3 & 200 & 32.1 & 12.7 & 4.6 & 16.1 & 6.4 \\
\hline & \multicolumn{4}{|c|}{ Mean value \pm SD } & $4.9 \pm 0.3$ & $16.0 \pm 0.2$ & $5.8 \pm 0.7$ \\
\hline & RedR1 & 200 & 31.0 & 11.9 & 5.5 & 15.5 & 6.0 \\
\hline & RedR2 & 200 & 28.6 & 12.0 & 6.2 & 14.3 & 6.0 \\
\hline & RedR3 & 200 & 30.9 & 13.0 & 6.8 & 15.5 & 6.5 \\
\hline & \multicolumn{4}{|c|}{ Mean value \pm SD } & $6.1 \pm 0.7$ & $15.1 \pm 0.5$ & $6.2 \pm 0.3$ \\
\hline
\end{tabular}

Legend: CPH: cocoa pod husk; SD: standard deviation. No significant differences were observed between geographical origins.

Table 6. Physical characteristics of pellets from green raw materials.

\begin{tabular}{ccccc}
\hline Parameter & MSB & MBT & CPH & CBS \\
\hline Diameter (mm) & $8.2 \pm 0.2$ & $8.1 \pm 0.2$ & $8.1 \pm 0.3$ & $8.2 \pm 0.3$ \\
Length (mm) & $15.2 \pm 0.4$ & $15.2 \pm 0.4$ & $15.4 \pm 0.5$ & $15.2 \pm 0.2$ \\
Broken Pellets (\%) & $11 \pm 3$ & $12 \pm 3$ & $652 \pm 20$ & $13 \pm 3$ \\
Density (kg/m $\left.{ }^{3}\right)$ & $650 \pm 15$ & $40 \pm 17$ & $3 \pm 1$ & $645 \pm 18$ \\
Fines (\%) & $4 \pm 1$ & $98 \pm 4$ & $98 \pm 3$ & $6 \pm 1$ \\
Retained in sieve 1/8' & $98 \pm 4$ & $5.0 \pm 0.4$ & $5.2 \pm 0.4$ & $96 \pm 4$ \\
Moisture (\%) & $4.8 \pm 0.5$ & $5.0 \pm 0.5$ \\
\hline
\end{tabular}

Legend: MSB: mango stem bark; MBT: mango branch trees; CPH: cocoa pod husk; CBS: cocoa bean shell.

\subsubsection{GRM Extraction}

- Mango: BGE yields from MSB were higher than MBT for both varieties (Haden and Tommy Atkins). The best yield was obtained from the Haden variety, from the Baní farm, with $12 \%$. The lowest yield was obtained for MBT from the Haden variety, from the Azua farm, however, this GRM had the highest polyphenol content (PPC), and, 
therefore, the highest mangiferin (MF) content. MF content in BGE polyphenol fraction ranged from $41.6 \%$ (MBT Tommy Atkins variety) to $55.4 \%$ (MSB Haden variety). The higher MF contents were found for the Haden variety in both MSB and MBT. All the BGE had similar water content. Results of the GRM extraction and quality control are shown in Table 7. Microbiological quality control was performed successfully for all lots (results not shown);

- Cocoa: BGE yields from CBS are shown in Table 8. Since no significant differences were observed in the PPC values for both geographical origin and pod color, the samples were homogenized in order to run the pilot plant batches. Due to the low yields of $\mathrm{CPH}$ (below 6\%), BGE extraction from this GRM was not performed. Pellets from the $\mathrm{CPH}$ will be used for feed formulations and the results will be shown elsewhere. CBS-PPC was around $28 \mathrm{~g} / 100 \mathrm{~g}$ and approximately $50 \%$ of its content $(13.9 \mathrm{~g})$ was a mixture of five different types of OPA.

Table 7. Yield and quality determinations of mango bioactive green extract.

\begin{tabular}{|c|c|c|c|c|c|c|c|}
\hline \multirow{2}{*}{ Farm } & \multirow{2}{*}{ Batch } & \multicolumn{3}{|c|}{ MSB/MBT } & \multicolumn{3}{|c|}{ Quality Control } \\
\hline & & GRM (kg) & BGE (kg) & Yield (\%) & Water (\%) & PPC (g/100 g) & MF (g/100 g) \\
\hline \multirow{6}{*}{ P. Plata } & ESBTA01 & 32 & 3.1 & 9.7 & 5.2 & 15.6 & 12.5 \\
\hline & ESBTA02 & 32 & 3.2 & 10.0 & 4.8 & 14.4 & 12.2 \\
\hline & ESBTA03 & 32 & 3.4 & 10.6 & 3.9 & 21.2 & 18.0 \\
\hline & ESBTA04 & 32 & 3.2 & 10.0 & 5.0 & 15.1 & 11.3 \\
\hline & ESBTA05 & 32 & 3.0 & 9.4 & 4.5 & 16.5 & 12.7 \\
\hline & \multicolumn{3}{|c|}{ Mean value $\pm S D$} & $9.9 \pm 0.7$ & $4.7 \pm 0.8$ & $16.2 \pm 1.5$ & $13.3 \pm 2.0$ \\
\hline \multirow{12}{*}{ Baní } & ESBH01 & 32 & 3.8 & 11.9 & 6.0 & 16.4 & 13.9 \\
\hline & ESBH01 & 32 & 3.6 & 11.3 & 4.5 & 17.8 & 14.4 \\
\hline & ESBH01 & 32 & 4.0 & 12.5 & 5.5 & 15.0 & 11.3 \\
\hline & ESBH01 & 32 & 3.8 & 11.9 & 5.0 & 14.9 & 10.7 \\
\hline & ESBH01 & 32 & 4.0 & 12.5 & 4.8 & 15.1 & 12.0 \\
\hline & \multicolumn{3}{|c|}{ Mean value \pm SD } & $12.0 \pm 0.6^{a}$ & $5.2 \pm 0.8$ & $15.8 \pm 1.5$ & $12.5 \pm 1.7$ \\
\hline & EBTTA01 & 32 & 3.3 & 10.2 & 4.0 & 14.0 & 9.8 \\
\hline & EBTTA02 & 32 & 3.0 & 9.4 & 4.4 & 14.2 & 10.6 \\
\hline & EBTTA03 & 32 & 3.1 & 9.7 & 5.2 & 13.4 & 8.1 \\
\hline & EBTTA04 & 32 & 3.2 & 10.0 & 4.2 & 13.8 & 9.2 \\
\hline & EBTTA05 & 32 & 3.0 & 9.4 & 4.0 & 14.2 & 9.2 \\
\hline & \multicolumn{3}{|c|}{ Mean value $\pm S D$} & $9.7 \pm 0.5^{b}$ & $4.4 \pm 0.8$ & $13.9 \pm 0.5^{b}$ & $9.4 \pm 1.2^{a b d}$ \\
\hline \multirow{6}{*}{ Azua } & EBTH01 & 32 & 2.3 & 7.2 & 5.1 & 15.5 & 13.1 \\
\hline & EBTH02 & 32 & 2.5 & 7.8 & 4.8 & 16.2 & 13.0 \\
\hline & ЕВTH03 & 32 & 2.3 & 7.2 & 4.2 & 16.8 & 12.9 \\
\hline & EBTH04 & 32 & 2.6 & 8.1 & 5.5 & 16.0 & 12.8 \\
\hline & ЕВTH05 & 32 & 2.8 & 8.8 & 5.0 & 17.4 & 15.7 \\
\hline & \multicolumn{3}{|c|}{ Mean value $\pm S D$} & $7.8 \pm 1.0^{a b c}$ & $4.9 \pm 0.7$ & $16.2 \pm 1.2^{c}$ & $13.5 \pm 0.8^{c}$ \\
\hline
\end{tabular}

Legend: MSB: mango stem bark; MBT: mango branch tree; GRM: green raw material; BGE: bioactive green extract; PPC: polyphenol content; MF: mangiferin; ESBTA: extract stem bark Tommy Atkins; ESBH: extract stem bark Haden; EBTTA: extract branch tree Tommy Atkins; EBTH: extract branch tree Haden; SD, standard deviation $(p>0.05)$. Letters indicate significant differences.

Table 8. Yield and quality determinations of cocoa bean shell-bioactive green extract.

\begin{tabular}{|c|c|c|c|c|c|c|}
\hline \multirow{2}{*}{ Batch } & \multicolumn{3}{|c|}{ CBS } & \multicolumn{3}{|c|}{ Quality Control } \\
\hline & GRM (kg) & BGE (kg) & Yield (\%) & Water (\%) & PPC (g/100 g) & (PAE g/100 g) \\
\hline 01 & 32 & 6.4 & 20.0 & 5.0 & 28.2 & 14.1 \\
\hline 02 & 32 & 6.2 & 19.4 & 4.8 & 27.9 & 13.7 \\
\hline 03 & 32 & 6.6 & 20.6 & 5.1 & 28.3 & 14.0 \\
\hline 04 & 32 & 6.0 & 18.8 & 5.2 & 28.0 & 13.9 \\
\hline 05 & 32 & 6.1 & 19.1 & 4.9 & 28.1 & 14.0 \\
\hline \multicolumn{3}{|c|}{ Mean value \pm SD } & $19.5 \pm 0.8$ & $5.0 \pm 0.2$ & $28.1 \pm 0.2$ & $13.9 \pm 0.2$ \\
\hline
\end{tabular}

Legend: CBS: cocoa bean shell; GRM: green raw material; BGE: bioactive green extract; PPC, polyphenol content; PAE: proanthocyanidin extract; SD: standard deviation. 


\subsection{Bioactive Ingredients}

\subsubsection{Mango}

The results of the HPLC-DAD analysis of the MSB-BGE and MBT-BGE for the Haden variety are shown in Table 9. The components were identified per retention times as referred to pure standards. Gallic acid $(0.7-1.3 \%)$, methyl gallate (1.6-1.8\%), propyl gallate (1.7\%), catechin (5.0-7.4\%), epicatechin (4.4-6.3\%), MF (76.2-77.5\%), iso-MF (5.2-6.9\%), and quercetin $(0.8-1.9 \%)$ could be identified in BGE from both mango GRM (Haden variety). The MF content ranged from $10.5 \mathrm{~g} / 100 \mathrm{~g}$ d.w. (MBT) to $12.0 \mathrm{~g} / 100 \mathrm{~g}$ d.w. (MSB). In terms of MF content, the Tommy Atkins variety had lower concentrations than the Haden variety (results not shown). The MF extracted from both MSB and MBT were identical qualitatively, in terms of proportion of MF:isoMF. We could obtain pure MF (90.3\% purity, HPLC), with $80 \%$ yield from BGE.

Table 9. HPLC-DAD analysis of bioactive green extracts from mango stem bark and branch tree, Haden variety.

\begin{tabular}{|c|c|c|c|c|c|c|c|}
\hline \multirow{2}{*}{ Component } & \multirow{2}{*}{ RT (min) } & \multicolumn{3}{|c|}{ MSB } & \multicolumn{3}{|c|}{ MBT } \\
\hline & & Peak Area & $\%$ & $\mathrm{~g} / 100 \mathrm{~g}$ & Peak Area & $\%$ & $\mathrm{~g} / 100 \mathrm{~g}$ \\
\hline Gallic acid & $4.5 \pm 0.5$ & 2343.55 & 1.3 & $0.2 \pm 0.1$ & 1451.80 & 0.7 & $0.1 \pm 0.1$ \\
\hline Unknown & $5.8 \pm 0.8$ & 1180.88 & 0.6 & $0.1 \pm 0.1$ & 1543.28 & 0.8 & $0.1 \pm 0.1$ \\
\hline Methyl gallate & $7.2 \pm 1.5$ & 3454.01 & 1.8 & $0.3 \pm 0.1$ & 3201.06 & 1.6 & $0.2 \pm 0.1$ \\
\hline Propyl gallate & $8.4 \pm 1.0$ & - & - & - & 3255.45 & 1.7 & $0.2 \pm 0.1$ \\
\hline (+) Catechin & $11.8 \pm 1.2$ & 9333.03 & 5.0 & $0.8 \pm 0.5$ & $14,517.77$ & 7.4 & $1.0 \pm 0.7$ \\
\hline (-) Epicatechin & $13.5 \pm 1.5$ & $11,666.30$ & 6.3 & $1.0 \pm 0.4$ & 8710.67 & 4.4 & $0.6 \pm 0.6$ \\
\hline Mangiferin & $14.6 \pm 0.8$ & $141,745.50$ & 76.2 & $12.0 \pm 0.5$ & $152,436.70$ & 77.5 & $10.5 \pm 0.7$ \\
\hline Isomangiferin & $15.0 \pm 0.6$ & $12,832.93$ & 6.9 & $1.1 \pm 0.3$ & $10,162.44$ & 5.2 & $0.7 \pm 0.2$ \\
\hline Quercetin & $19.6 \pm 1.0$ & 3499.89 & 1.9 & $0.3 \pm 0.2$ & 1496.00 & 0.8 & $0.1 \pm 0.1$ \\
\hline Total & & & & $16.2 \pm 1.2$ & & & $13.5 \pm 0.8$ \\
\hline
\end{tabular}

Legend: MSB: mango stem bark, MBT: mango branch tree, RT: retention time.

\subsubsection{Cocoa}

The results of the HPLC-DAD analysis of the CBS-BGE and OPA-rich extract are shown in Table 10. Catechin, $9.2 \pm 2.2 \mathrm{~g} / 100 \mathrm{~g}$, and epicatechin, $18.4 \pm 2.6 \mathrm{~g} / 100 \mathrm{~g}$ were the main single BGE polyphenols. The proportions of oligomers in the OPA-rich extract were estimated by internal normalization using catechin as the internal standard as follows: $12 \%$ dimer, $19 \%$ trimer, $22 \%$ tetramer, $25 \%$ pentamer, and $19 \%$ hexamer, with retention times between 31 and $40 \mathrm{~min}$ in our experimental conditions. These oligomers could be identified per comparison of similar retention times with reported results [21].

Table 10. HPLC-DAD analysis of cocoa bean shell-oligomeric proanthocyanidin-rich extract.

\begin{tabular}{|c|c|c|c|c|}
\hline \multirow{2}{*}{ Component } & \multirow{2}{*}{ RT (min) } & \multicolumn{3}{|c|}{ CBS Extract } \\
\hline & & Peak Area & $\%$ & $\mathrm{~g} / 100 \mathrm{~g}$ \\
\hline \multicolumn{2}{|c|}{ Single polyphenols (total) } & & 50.6 & $14.2 \pm 0.2$ \\
\hline$(+)$ Catechin & $9.8 \pm 1.0$ & $16,781.76$ & 7.5 & $2.1 \pm 0.5$ \\
\hline (-) Epicatechin & $11.4 \pm 1.2$ & $88,703.65$ & 39.5 & $11.1 \pm 0.4$ \\
\hline Quercetin & $20.9 \pm 1.5$ & 7991.32 & 3.6 & $1.0 \pm 0.5$ \\
\hline \multicolumn{2}{|c|}{ Oligomeric Proanthocyanidins (total) } & & 49.4 & $13.9 \pm 0.2$ \\
\hline -Dimer & $31.4 \pm 2.2$ & $16,822.41$ & 7.5 & $2.1 \pm 0.1$ \\
\hline -Trimer & $33.8 \pm 2.0$ & $21,576.55$ & 9.6 & $2.7 \pm 0.2$ \\
\hline -Tetramer & $36.1 \pm 1.8$ & $23,973.95$ & 10.6 & $3.0 \pm 0.3$ \\
\hline -Pentamer & $38.2 \pm 1.5$ & $27,170.48$ & 12.1 & $3.4 \pm 0.3$ \\
\hline -Hexamer & $40.0 \pm 3.0$ & $21,567.98$ & 9.6 & $2.7 \pm 0.2$ \\
\hline Total & & & & $28.1 \pm 0.2$ \\
\hline
\end{tabular}




\section{Discussion}

\subsection{PROMANCOA Technology Development for Mango Agricultural Biowastes}

The GRM collection and storage following an SOP is crucial for the quality specifications of the end-product after its processing. Variables, such as land geographic site, soil type, part to be collected (i.e., fruit, peel, kernel, SB or BT), and procedure for collection, must be considered for the adequate elaboration of SOP. PROMANCOA modular technology (PMT) considered two GRM for standardization, SB and BT. The mango GRM from the Haden variety was better than the Tommy Atkins variety in terms of PPC and MF; therefore, future commercial exploitation of antioxidant-rich extracts from mango GRM should consider this variety difference. Mango variety may affect these parameters as was demonstrated i.e., for its mineral content [25]. Another factor to be considered for industrial production is the GRM potential to be collected for extraction. MBT could be collected in higher amounts than MSB, which has additional difficulties for its collection, including risks of tree damage.

The low density of mango GRM was a problem for handling and storage, and therefore procedures for producing mango GRM pellets was needed. We could obtain a GRM volume reduction of $18 \%$ for both MSB and MBT with a low water content $(5 \%)$, which facilitated the subsequent extraction process. These wood-derived pellets were similar physically to pellets from bamboo and pine stem bark [26].

Phenolic antioxidants of mango GRM were studied being that MF is the main component of the polyphenol fraction $(7 \mathrm{~g} / 100 \mathrm{~g}$ d.w.) [27]. The presence of iso-MF in purified MF was reported in several Chinese mango varieties [28]. MF purity could not be increased above $90 \%$ by further recrystallizations, which may be done by preparative chromatography with macroporous resins as reported elsewhere [29]. Structures of both isomers are highly similar (see Figure 2), and therefore its separation is time-consuming.<smiles>O=c1c2cc(O)c(O)cc2oc2cc(O)c([C@H]3OC(CO)C(O)[C@H](O)C3O)c(O)c12</smiles>

Mangiferin<smiles>O=c1c2cc(O)c(O)cc2oc2c(C3OC(CO)C(O)C(O)[C@H]3O)c(O)cc(O)c12</smiles>

Isomangiferin

Figure 2. Chemical structures of mangiferin and isomangiferin isolated from mango BGE.

MF has received considerable attention not only for its antioxidant properties, but as a potential drug candidate for degenerative diseases [30], alongside its benefits as a nutraceutical supplement [31,32]. We demonstrated recently that isolated MF may not be the main responsible party for the antioxidant activity from mango extracts, but, rather, several MF derivatives, such as glucomangiferin and MF-galloyl and benzoyl derivatives [33]. The contribution of bioactive volatile compounds in mango extracts, such as terpenoids (eudesmane type), single phenols, and some steroids, should also be considered when analyzing the possible contribution of mango extract components to its antioxidant and other biological effects [34].

Classical solid-liquid extraction techniques similar to PMT have been reported for the valorization of mango fruit peel and seed kernel [35,36], but novel technologies, such as pressurized liquid extraction, supercritical fluid extraction, and sub-critical solvent extraction were also used for obtaining BGE from mango by-products [37]. The main advantage for PMT is the accessibility to equipment and processes that were established in the classical extraction industry. However, novel environmentally friendly technologies show several advantages in terms of selectivity and recovery efficiency [38]. 


\subsection{PROMANCOA Technology Development for Cocoa Agricultural Biowastes}

PMT considered one GRM for standardization (CPH), since CBS was collected directly from the cocoa factory using the standard industrial technology for cocoa production. The time between $\mathrm{CPH}$ collection and drying is critical because of its possible microbial contamination due to its high water content (above $85 \%$ ). In our case, $\mathrm{CPH}$ was collected carefully for research purposes and processed within $24 \mathrm{~h}$ after collection, but considering its possible utilization for industrial processing it would be difficult to standardize. Therefore, CPH technological development was studied only up to pelletization for animal feeding, and animal trials have to be designed in the future to prove its utility [39]. The very low CPH density (around $200 \mathrm{~kg} / \mathrm{m}^{3}$ ) was a problem for handling and storage, and we could increase that value up to $652 \mathrm{~kg} / \mathrm{m}^{3}$ through pelletization. The main use reported for $\mathrm{CPH}$ pellets has been as biofuel $[40,41]$, although problems in boilers may be present due to its high mineral content [42].

$\mathrm{CPH}$ has not been studied extensively as a source of antioxidant extracts [43]. OPA content in the exocarp of this GRM was reported to be between $8 \mathrm{mg} / \mathrm{g}$ and $170 \mathrm{mg} / \mathrm{g}$ [44]. The PPC in the pericarp was reported between $12.4 \mathrm{mg} / \mathrm{g}$ and $13.6 \mathrm{mg} / \mathrm{g}$, using supercritical $\mathrm{CO}_{2}$ extraction [45], which is considerably lower than those values in the exocarp, and the one reported in the present work for CBS-BGE $(18.1 \pm 0.2 \mathrm{mg} / \mathrm{g})$. The main polyphenolic components, which were identified in dried $\mathrm{CPH}$, were similar to those of CBS (quercetin, catechin, epicatechin, and gallic acid) [46]. The most extensive uses of $\mathrm{CPH}$ are as an organic fertilizer, for animal feeding, and as a source of renewable energy [47].

The single polyphenols and oligomers found in CBS-OPA-rich extract were quercetin, catechin, and epicatechin. The chemical structures of polyphenols and OPA are shown in Figure 3. Oligomers may be chains of catechin and epicatechin or its combinations, and were assigned by comparison of similar retention times with standards.<smiles>O=c1c(O)c(-c2ccc(O)c(O)c2)oc2cc(O)cc(O)c12</smiles>

(1)<smiles>Oc1cc(O)c2c(c1)O[C@H](c1ccc(O)c(O)c1)C(O)C2</smiles>

(2)<smiles>Oc1cc(O)c2c(c1)O[C@H](c1ccc(O)c(O)c1)[C@H](O)C2</smiles>

(3)

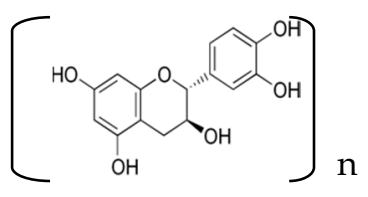

(4)

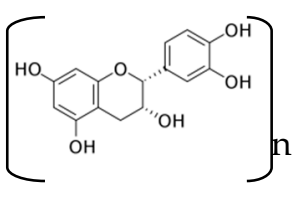

(5)

Figure 3. Chemical structures of polyphenols in the OPA-rich extract from CBS: (1) quercetin, (2) (+) catechin, (3) (-) epicathecin, (4) procyanidin (catechin type), and (5) procyanidin (epicatechin type). $n=2,3,4,5$ or 6.

CBS extracts showed higher levels of procyanidin oligomers, such as tetramers, pentamers, and hexamers, than grape seed extract [48]. However, concerning monomeric flavan-3-ols, such as catechin or epicatechin, grape seed extract has the highest proportion. In terms of dimer proanthocyanidins (B-type and gallate derivatives), no differences were observed [21]. Other authors [49] reported that the CBS-PPC (above $200 \mathrm{mg} / \mathrm{g}$ ) is much higher than in cocoa powder obtained from cocoa beans (max. $60 \mathrm{mg} / \mathrm{g}$ ). The most abundant reported flavonoids in CBS were catechin and epicatechin, between $6 \mathrm{mg} / \mathrm{g}$ and $17 \mathrm{mg} / \mathrm{g}$, respectively, and these values depend on the extraction conditions (i.e., solvents and temperature) and geographical origin [50]. Our CBS extract had significantly lower values of catechin $(2.1 \pm 0.5 \mathrm{~g} / 100 \mathrm{~g})$ and epicathechin $(11.1 \pm 0.4 \mathrm{~g} / 100 \mathrm{~g})$ as compared with those previous reports, probably due to its major condensation into oligomers, which 
were comparatively higher in our cocoa GRM $(13.9 \pm 0.2 \mathrm{~g} / 100 \mathrm{~g})$ as compared with CBS collected from cocoa of different geographic origins [51].

Several researchers have tried to improve CBS-PPC by using different techniques such as supercritical solvent extraction [52], pulsed electric fields [53], or ultrasound techniques [54], which are not common industrial procedures and require high investment. The high PPC and the high-molecular-weight OPA content found in Dominican CBS deserves further research considering not only the extraction technique, but the type of cocoa fermentation and drying solar temperature. Nevertheless, it seems that PMT offers an attractive alternative in terms of producing OPA-rich extracts for the food and pharmaceutical industries.

\subsection{PROMANCOA Technology for Other Agricultural Biowastes}

The discovery of new and sustainable approaches for growing foods and efficiently utilizing biomass resources is a global priority, with the human population on Earth predicted to reach 9 billion in 2050. To achieve this, more sustainable farming practices need to be developed for food production. There is currently a significant change occurring in consumer purchasing behavior worldwide. Foods that are perceived as healthy or marketed as health-promoting are attracting increasing demand [55]. Agricultural commodities do produce a huge amount of waste, termed as agricultural waste or biomass. Innovation in managing such a vast amount of agricultural waste or biomass is a continuous challenge and recent trends favor the utilization of this biomass for value-added purposes to fulfill needs in areas such as renewable energy, fiber composites and textiles, food alternatives, and livestock feed [56]. Therefore, the development of a more integrated approach to resource management, based on sustainable strategies along the whole supply chain (to valorize residues, by-products, and wastes), is essential.

The public perception regarding utilization of agricultural biowastes as raw material for producing food and food supplements depends mainly on two factors: (i) whether genetic material is involved or not, and (ii) the particular cultural attitude to technological development. Compared with other food hazards, genetically engineered food was perceived $(81 \%)$ as a moderately severe risk, or very unknown risk [57]. When genetic manipulations are not involved in food production, new technologies are perceived $(>80 \%)$ as beneficial for human consumption and the environment [58]. Most of the studies that were performed on public perception of new food technologies, genetically modified or not, were conducted in developed nations, but this perception changes dramatically when analyzing the perception in non-developed countries. Generally, there is a positive perception towards new food technologies in developing nations, where more urgent needs in terms of food availability and nutritional content are present. Additionally, perceived levels of risk may be smaller due to trust in government, positive perceptions of science, and positive media influences [59].

Antioxidants are known to be present in many plant-derived products, and are accepted worldwide as food supplements, which are legally defined as foodstuffs with the purpose to supplement the normal diet with a nutritional or physiological effect, alone or in combination. Novel food ingredients concerns the placing on the market of foods and food ingredients, including food plant supplements, which have not been used for human consumption to a significant degree, must not present a danger for the consumer, mislead the consumer, and differ from foods or food ingredients that they are intended to replace to such an extent that their normal consumption would be nutritionally disadvantageous for the consumer [60]. Mango and cocoa agricultural production fulfill the requisites previously mentioned as acceptable sources for producing novel ingredients for food, cosmetics, and pharmaceutical industries, and therefore our results are a step forward in introducing new BGE into these markets. 


\section{Materials and Methods}

\subsection{Module 1: GRM Collection and Storage}

4.1.1. Mango Stem Bark (MSB)

MSB was collected during 2018 and 2019 (autumn season) as follows:

- Stem was marked with a chalk at $25 \mathrm{~cm}$ below the lowest tree branch and $25 \mathrm{~cm}$ above the highest root. Using a compass, the collection was performed first in the stem side looking to the north, and in the south afterwards;

- With the use of a manual circular saw (diameter $5 \mathrm{~cm}$ ) bark was marked, with not more than $2 \mathrm{~cm}$ depth, making a rectangle of around $10 \mathrm{~cm}$ width and up to $50 \mathrm{~cm}$ height, depending on the tree size;

- The bark was separated without damaging the stem, with specially designed tools, in clockwise direction, first from the north side, and after that from the south side;

- $\quad$ MSB pieces were cleaned manually from dust and residues and collected in sealed polystyrene bags, approximately $50 \mathrm{~kg}$ per bag, and identified with a card indicating location, variety, date of collection, and the operator's name. The bags were stored in the dark (at room temperature), and transported to the processing plant within 7 days of collection.

\subsubsection{Mango Branch Trees (MBT)}

MBT was collected between September 2018 and December 2019 as follows:

- Branch trees were cut and left in the field for one week for solar drying;

- Solar dried MBT was milled in the field with a crusher and collected in polystyrene sealed bags, approximately $50 \mathrm{~kg}$ per bag, and identified with a card indicating location, variety, date of collection, and operator name. The bags were stored in the dark (at room temperature) and transported to the processing plant within 7 days of collection.

\subsubsection{Cocoa Pod Husk (CPH)}

CPH was collected during 2018 and 2019 (spring season) as follows:

- Cocoa plants in the field were selected randomly according to the presence of greenyellowish or red-orange pods. Green-yellowish and red-orange pods were collected separately

- The outer mass from the pods were collected after a careful longitudinal cut, taking care not to cut the cocoa seeds;

- $\quad$ rude CPH was collected in plastic tanks (around $200 \mathrm{~kg} /$ tank), and seeds were collected in seed containers for subsequent fermentation. $\mathrm{CPH}$ water content was around $85 \%$;

- The plastic tanks were transported to the pilot plant within 24 to $48 \mathrm{~h}$ after collection for subsequent drying.

Samples were processed within $24 \mathrm{~h}$ after collection.

\subsubsection{Cocoa Bean Shell (CBS)}

Collected cocoa seeds in the field, as described above, were submitted to fermentation, hot-air drying, and subsequent milling in order to obtain dried cocoa seeds for chocolate production in an industrial plant (Rizek Cacao, San Francisco de Macorís, Dominican Republic). A residue from this process is the CBS, which was directly submitted for BGI extraction without any other treatment. CBS was collected in sealed polystyrene bags (approx. $30 \mathrm{~kg}$ each), and stored in the dark (at room temperature). CBS samples were processed within 30 days of collection.

\subsection{Module 2: GRM Processing}

\subsubsection{GRM Drying}

- Mango: Each lot (100 kg) was dried within 72 and 120 h, depending on the initial water content, and divided in two sections, A and B, with manual removal every 
$24 \mathrm{~h}$. Average solar global radiation was between 5.25 and $5.50 \mathrm{kWh} / \mathrm{m}^{2} /$ day [61]. Approximately $2 \mathrm{~kg}$ of mango GRM (MSB or MBT) were brought into 304 stainless steel (SS) trays with 60-mesh size steel in the bottom. SS trays were put in the solar drying unit (see Supplementary Information). Hot air drying was subsequently performed in a rotary dryer (Girbau, Barcelona, Spain, Model E660) at $60^{\circ} \mathrm{C}$, with a rotary speed of $80 \mathrm{rpm}$. The dryer drum was covered with a 60-mesh cloth in order to avoid particle entrance into the dryer motor. Each lot from solar drying was divided in two lots of $50 \mathrm{~kg}$ each and dried with hot air for $3 \mathrm{~h}$. MBT had low water content (between 10\% and $15 \%$ ), and therefore solar drying was not necessary;

- Cocoa: Approximately $1.5 \mathrm{~kg}$ of $\mathrm{CPH}$ was put in each tray of the solar drying unit as described above. Each lot $(75 \mathrm{~kg}$ ) was dried within 96 and $168 \mathrm{~h}$ depending on the initial water content, and divided in two dryer sections, A and B, in a similar array as describe for mango. $\mathrm{CPH}$ from the solar drying unit was submitted for drying at a rotary hot-air dryer (Girbau, Barcelona, Spain, Model E660) at $60^{\circ} \mathrm{C}$, with a rotary speed of $80 \mathrm{rpm}$. The dryer drum was covered with a 120-mesh cloth in order to avoid particle entrance into the dryer motor. Each lot from solar drying was divided into two lots of approx. $37 \mathrm{~kg}$ each. and dried with hot air for $4 \mathrm{~h}$.

\subsubsection{GRM Milling}

- Mango: Both MSB and MBT were milled after drying in a hammer mill (Buskirk, Indiana, USA, Model HM1000) equipped with a $20 \mathrm{HP}(3 \mathrm{p})$ motor and screen holes of $10 \mathrm{~mm}$ (first step) and $3 \mathrm{~mm}$ (second step). Starting GRM sizes were between 5 and $100 \mathrm{~mm}$;

- Cocoa: CBS was milled in the same device in a single step with $3 \mathrm{~mm}$ screen holes. Starting CBS sizes were between 2 and $20 \mathrm{~mm}$.

\subsubsection{GRM Pelletization}

Milled GRM from both sources (mango and cocoa) were pelletized for subsequent storage until extraction in a pelletizer (Buskirk, Indiana, USA, Model PM1230) connected to the hammer mill through a conveyor. The pellets were obtained by pressing the milled GRM against a SS metal plate at high pressure. The average pellets size was $8 \mathrm{~mm}$ (diameter) $\times 15 \mathrm{~mm}$ (length). The collected pellets were placed in PE bags, which were sealed under vacuum $\left(32 \mathrm{~kg}\right.$ each) and stored at a controlled temperature $\left(25^{\circ} \mathrm{C}\right)$ until extraction within the next 30 days (see Figure 4). The physical quality of the GRM pellets was evaluated according to the Pellet Fuel Institute, USA [62] as follows:

- Pellet Dimension: Diameter and length of cylindrical pellets were measured using a digital Vernier caliper and results were expressed as the mean value \pm standard deviation $(p>0.05)$;

- Pellet Density: 20 individual pellets were weighed in a laboratory balance (Ohaus, NJ, USA, Model FD3H) and its volume calculated according to the Equation (1). Pellet density was calculated according to Equation (2);

- Pellets fines: Pellet fines content was determined using a 1/8-inch $(3.18 \mathrm{~mm})$ wire screen sieve (Retsch, Haan, Switzerland, Model AS200);

- Moisture: Pellet moisture (\%) was determined with an IR-Balance (Radwag, Puszczykowo, Poland, Model PRM50).

$$
\begin{gathered}
\mathrm{V}_{\mathrm{p}}=\frac{\pi}{4 \mathrm{~d}^{2} \mathrm{~L}} \\
\rho_{\mathrm{p}}=\frac{\mathrm{m}_{\mathrm{p}}}{\mathrm{V}_{\mathrm{p}}}
\end{gathered}
$$

where $\mathrm{V}_{\mathrm{p}}$ is volume of an individual pellet $\left(\mathrm{cm}^{3}\right)$; $\mathrm{d}$ is diameter of an individual pellet $(\mathrm{mm})$; $\mathrm{L}$ is length of an individual pellet $(\mathrm{mm}) ; \rho_{\mathrm{p}}$ is density of an individual pellet $\left(\mathrm{kg} / \mathrm{m}^{3}\right)$; and $\mathrm{m}_{\mathrm{p}}$ is mass of an individual pellet $(\mathrm{g})$. 


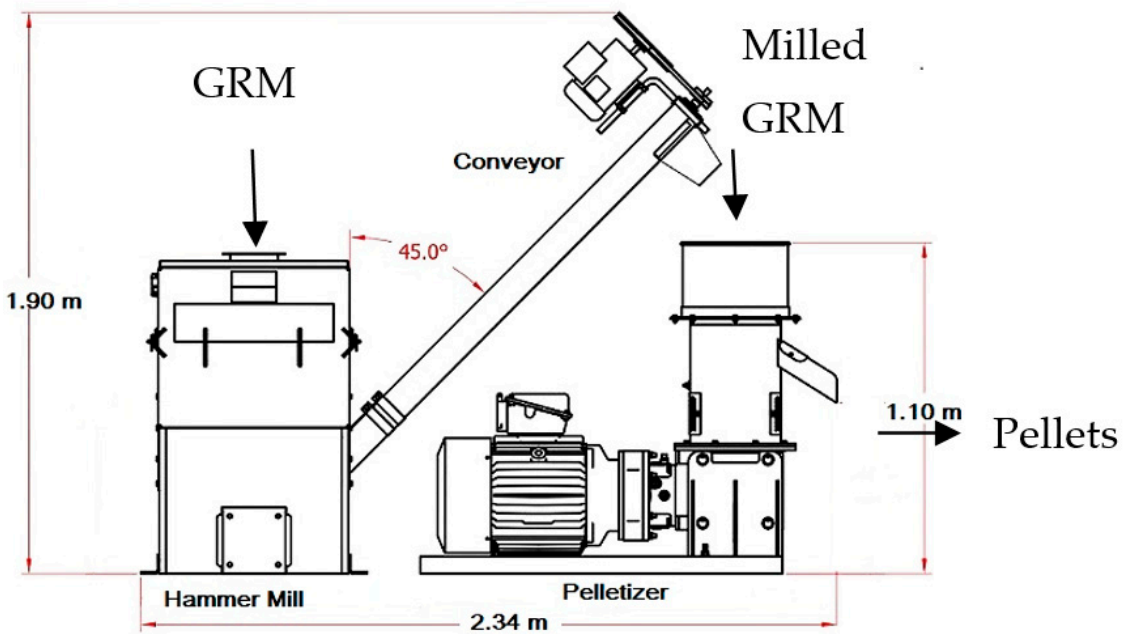

Figure 4. Pelletization pilot plant. The hammer mill was fed at the upper side with dried GRM, milled GRM was transported through the conveyor to the Pelletizer (PM1230), and pellets were collected and sealed in PE bags under vacuum.

\subsection{Module 3: GRM Extraction}

\subsubsection{Stirred-Tank Extraction}

Thirty-two kilograms of dried and pelletized MBS or MBT were put into a 250 L SS jacketed-stirred tank extractor, previously filled with $220 \mathrm{~L}$ of deionized water (mango) or water:ethanol (1:1) for CBS. Extraction temperature was fixed at $80 \pm 5{ }^{\circ} \mathrm{C}$, and agitation speed at $70 \pm 5 \mathrm{rpm}$. Extraction was performed by $2 \mathrm{~h}$, once the mixture reached the appropriate temperature. After this, heating was stopped and the mixture was cooled until room temperature (approx. $30^{\circ} \mathrm{C}$ ). Five batches for each GRM were performed and the results were expressed as a mean value $\pm \mathrm{SD}$.

\subsubsection{Extract Filtration}

Extract was filtered through a polystyrene multifilament cloth using a filter press (Chayo Ltd., Hangzhou, China, Model XAJ5/400-Uk.) with five gasketed plates, $40 \times 40$ $\mathrm{cm}$, at $10 \mathrm{~L} / \mathrm{min}$ flow. Cloth mesh diameters were 60 and 120 for MSB/MBT and CBS, respectively. The filtered extract was collected in $200 \mathrm{~L}$ PP tanks, with an adequate amount of sodium benzoate (preservative), and stored in a cool room $\left(10 \pm 2{ }^{\circ} \mathrm{C}\right)$ until spray drying.

\subsubsection{Spray Drying}

The extract was left to stand at room temperature before spray drying and brought into the spray dryer feeding tank. The input flow was set at $70 \mathrm{~mL} / \mathrm{min}$; inlet air temperature, $170{ }^{\circ} \mathrm{C}$; outlet air temperature, $90^{\circ} \mathrm{C}$; and disc revolutions at $21,700 \mathrm{rpm}$, for obtaining a drying yield about $4 \mathrm{~L} / \mathrm{h}$ (Pilotech, Shanghai, China, Model YC-018). The BGE was put into $\mathrm{PE}$ bags, weighed, and sealed under vacuum for storage.

\subsection{Module 4: Quality Control}

\subsubsection{Bioactive Green Extract (BGE)}

The BGE was analyzed by standard methods of microbiological quality control for total coliforms, mesophilic content, mold, fungi, Clostridium sp., and Salmonella sp. [63], and for its physical-chemical quality specifications. Water content was determined with a moisture analyzer (Radwag, Puszczykowo, Poland, Model PMR 50). MF and OPA content for MSBBGE, MBT-BGE, and CBS-BGE were determined by HPLC-DAD as described hereinafter.

\subsubsection{Bioactive Green Ingredient (BGI)}

- Polyphenol Content (PPC): The polyphenol content (PPC) of mango- and cocoaextracts was determined by a modified Folin-Ciocalteu method using a catechin- 
equivalent standard [27]. The extracts $(1.15 \mathrm{mg})$ were dissolved in methanol $(2 \mathrm{~mL})$ and the solution was diluted ten-fold with distilled water. Folin-Ciocalteu reagent $(0.5 \mathrm{~mL})$ was added to the diluted solution, followed by $0.5 \mathrm{~mL}$ of sodium carbonate, $100 \mathrm{~g} / \mathrm{L}$ solution. The absorbance was measured at $700 \mathrm{~nm}$ (Thermo Scientific, MA, USA, Genesys 10 spectrophotometer) with a blank sample (water plus reagents) in the reference cell ( $1 \mathrm{~cm}$-depth quartz). Quantification was performed by plotting the absorbance value in a calibration curve of $(+)$ catechin used as standard phenol;

- Mangiferin: Pure MF was obtained from MSB-BGE and MBT-BGE by recrystallization in a mixture of acetone:water (5:1) through a modified procedure [64]. The purity of the re-crystallized MF was checked by HPLC (Young Lin, Korea) with a quaternary pump (Model YL-9110), autosampler (YL-9150), and a DAD (diode-array detector, YL-9160). The column (RP-18, $5 \mu \mathrm{m}, 250 \times 4 \mathrm{~mm}$ i.d., Merck, Darmstadt, Germany) was placed in a column oven (YL-9131) at $30^{\circ} \mathrm{C}$. The solvents were degassed (YL-9101) and the injection volume was $20 \mu \mathrm{L}$. The mobile phase used was acetic acid $(0.1 \%)$ in water (A) and acetic acid (0.1\%) in methanol (B). The ratio of A:B increased from 9:1 to 1:9 in $35 \mathrm{~min}$ at a flow rate of $1 \mathrm{~mL} / \mathrm{min}$. The data acquisition and peak integration analysis was performed using Clarity software (Data Apex, Czech Republic);

- OPA-rich Extract: CBS-BGE was defatted with n-hexane in a Soxhlet apparatus, and subsequently extracted with a mixture of ethanol:water (7:3), $\mathrm{pH}=6.5$ (with acetic acid) in a ratio of 1:5 at room temperature with agitation $(30 \mathrm{rpm})$ for $30 \mathrm{~min}$. The mixture was filtered under vacuum, the filtrate was spray dried and the solid was recrystallized in a mixture of acetone:water (5:1). OPA content (catechin- and epicatechin types) was determined by HPLC-DAD as described above for MF, with the following changes in experimental conditions: in the mobile phase, the formic acid $(0.1 \%)$ was in water (A) and acetonitrile (B); the ratio of $\mathrm{A}: \mathrm{B}$ was increased from 1:9 to 9:1 in $35 \mathrm{~min}$; the flow rate was $0.5 \mathrm{~mL} / \mathrm{min}$; and the column temperature, $40^{\circ} \mathrm{C}$.

\subsubsection{Chemicals and Standards}

PA and HPLC grade solvents (n-hexane, methanol, acetone, and acetonitrile) and reagents (acetic acid, formic acid, sodium carbonate, and sodium benzoate) were purchased from J.T. Baker (USA). Folin-Ciocalteu reagent was purchased from Merck (Darmstadt, Germany). AquaMax (Ultra 360 and Ultra 370, Young Lin, Korea) was used for producing ultrapure water. The following standards were purchased from Sigma-Aldrich Co. (SaintLouis, MO, USA): gallic acid (97.5\% purity, MW: 170.12, white amorphous solid), methyl gallate ( $98 \%$ purity, MW: 184.15 , white amorphous solid), propyl gallate $(98 \%$ purity, MW: 212.20, white amorphous solid), (+)-catechin (97\% purity, MW: 290.27, colorless amorphous solid), (-)-epicatechin (90\% purity, MW: 290.27, colorless amorphous solid), quercetin (95\% purity, MW: 302.24 , colorless amorphous solid), and mangiferin (99\% purity, $\mathrm{MW}=422.34$, white amorphous solid). OPA standards (A1, A2, B1, B2, and B3) were kindly provided by the University of Salerno (Italy).

See Flowchart S1 in Supplementary Material.

\section{Conclusions}

PROMANCOA modular technology (PMT) was developed at a pilot plant scale with four modules: (1) green raw material collection and storage; (2) green raw material processing (drying, milling, and pelletizing); (3) green raw material extraction (extraction, filtration, and spray drying); and (4) quality control (water content, polyphenol content, mangiferin content (mango), and oligomeric proanthocyanidin content (cocoa)) for the valorization of agricultural by-products of mango and cocoa crops. Mango bioactive green extracts from branch trees and stem bark had a polyphenol content of $13.5 \pm 0.8 \mathrm{mg} / 100 \mathrm{~g}$ and $16.2 \pm 1.2 \mathrm{mg} / 100 \mathrm{~g}$ d.w., respectively, with more than $75 \%$ of the main bioactive ingredient (mangiferin), and cocoa bioactive green extract from cocoa bean shell had a polyphenol content of $28.1 \pm 0.2 \mathrm{mg} / 100 \mathrm{~g} \mathrm{~d} . \mathrm{w}$. with around $50 \%$ of oligomeric proanthocyanidins. Our results show the feasibility of producing antioxidant-rich extracts from mango and 
cocoa agricultural by-products as acceptable sources for producing novel ingredients for food, cosmetics, and pharmaceutical industries, and, therefore, are a step forward for introducing new bioactive green ingredients into these markets. The main advantage for PMT is the accessibility to equipment and processes that have been established in the classical extraction industry.

Supplementary Materials: The following is available online at https:/ / www.mdpi.com/article/10 .3390/pr9081312/s1, Flowchart S1: PROMANCOA Modular Technology Graphic Chart Flow.

Author Contributions: Conceptualization, A.J.N.-S. and A.J.A.-G.; methodology, A.J.N.-S. and A.J.A.G.; formal analysis, A.J.N.-S. and A.J.A.-G.; investigation, A.J.N.-S., A.J.A.-G., and M.R.-M.; resources, A.J.N.-S. and M.R.-M.; data curation, A.J.N.-S. and A.J.A.-G.; writing-original draft preparation, A.J.N.-S.; writing-review and editing, A.J.N.-S., A.J.A.-G., and M.R.-M.; visualization, A.J.N.-S.; supervision, project administration, and funding acquisition, A.J.N.-S. All authors have read and agreed to the published version of the manuscript.

Funding: This research was funded by the Korean International Cooperation Agency (KOICA), South Korea; and the Ministry of Higher Education, Science and Technology (MESCYT), Dominican Republic, grant number KP-32/2018.

Institutional Review Board Statement: Not applicable.

Informed Consent Statement: Not applicable.

Data Availability Statement: The data presented in this study are available on request from the corresponding author.

Acknowledgments: The support of the Universidad Nacional Evangélica (UNEV), Dominican Republic, is gratefully acknowledged. Oxinat srl, and its Executive Director, Santiago Kalaf, for the commercial ventures. Marisol Ventura and Victor Espaillat for their support in collecting GRM. Keyla Salce and Deyrel Reynoso for administrative and accounting support.

Conflicts of Interest: The authors declare no conflict of interest. The funders had no role in the design of the study; in the collection, analyses, or interpretation of data; in the writing of the manuscript, or in the decision to publish the results.

\section{References}

1. Bocken, N.M.P.; de Pauw, I.; Bakker, C.A.; van der Grinten, B. Product design and business model strategies for a circular economy. J. Ind. Prod. Eng. 2016, 33, 308-320. [CrossRef]

2. Ghisellini, P.; Cialani, C.; Ulgiati, S. A Review on Circular Economy: The Expected Transition to a Balanced Interplay of Environmental and Economic Systems. J. Clean. Prod. 2016, 114, 11-32. [CrossRef]

3. Payne, J.; McKeown, P.; Jones, M.D. A circular economy approach to plastic waste. Polym. Degrad. Stab. 2019, 165, 170-181. [CrossRef]

4. Fischer, A.; Pascucci, S. Institutional incentives in circular economy transition: The case of material use in the Dutch textile industry. J. Clean. Prod. 2017, 155, 17-32. [CrossRef]

5. Campos, D.A.; Gómez-García, R.; Vilas-Boas, A.A.; Madureira, A.R.; Pintado, M. Management of Fruit Industrial By-Products-A Case Study on Circular Economy Approach. Molecules 2020, 25, 320. [CrossRef]

6. Toop, T.A.; Ward, S.; Oldfield, T.; Hull, M.; Kirby, M.E.; Theodorou, M.K. AgroCycle-developing a circular economy in agriculture. Energy Procedia 2017, 123, 76-80. [CrossRef]

7. Núñez-Sellés, A.J.; Delgado-Hernández, R.; Garrido-Garrido, G.; García-Rivera, D.; Guevara-García, M.; Pardo-Andreu, G.L. The paradox of natural products as pharmaceuticals: Experimental evidences of a mango stem bark extract. Pharmacol. Res. 2007, 55, 351-358. [CrossRef]

8. Oracz, J.; Nebesny, E. Antioxidant Properties of Cocoa Beans (Theobroma cacao L.): Influence of Cultivar and Roasting Conditions. Int. J. Food Prop. 2015, 19, 1242-1258. [CrossRef]

9. Núñez-Sellés, A.J. El Reto de la Terapia Antioxidante; Editorial Académica Española: Madrid, Spain, 2011; 208p, ISBN 978-3846565995. (In Spanish)

10. Belščak-Cvitanović, A.; Durgo, K.; Huđek, A.; Bačun-Družina, V.; Komes, D. Overview of polyphenols and their properties. In Polyphenols: Properties, Recovery and Applications; Galanakis, C.M., Ed.; Woodhead Publishing: Cambridge, MA, USA, 2018; pp. 3-44.

11. Hernández-Rodríguez, P.; Pabón Baquero, L.; Rodríguez Larrota, H. Flavonoids: Potential therapeutic agents by their anti-oxidant capacity. In Bioactive Compounds. Health Benefits and Potential Applications; Segura Campos, M.R., Ed.; Woodhead Publishing: Sawston, UK, 2019; pp. 265-288. [CrossRef] 
12. Pinto, M.; Palmeira, A.; Fernandes, C.; Resende, D.; Sousa, E.; Cidade, H.; Tiritan, M.; Correia-Da-Silva, M.; Cravo, S. From Natural Products to New Synthetic Small Molecules: A Journey through the World of Xanthones. Molecules 2021, $26,431$. [CrossRef]

13. Vivas, D.B.; Alvarez-Rivera, G.; Ocampo, A.F.G.; Morantes, S.J.; Sánchez-Camargo, A.D.P.; Cifuentes, A.; Parada-Alfonso, F.; Ibánez, E. Supercritical antisolvent fractionation as a tool for enhancing antiproliferative activity of mango seed kernel extracts against colon cancer cells. J. Supercrit. Fluids 2019, 152, 104563. [CrossRef]

14. Muñoz-Almagro, N.; Valadez-Carmona, L.; Mendiola, J.A.; Ibáñez, E.; Villamiel, M. Structural characterisation of pectin obtained from cacao pod husk. Comparison of conventional and subcritical water extraction. Carbohydr. Polym. 2019, 217, 69-78. [CrossRef] [PubMed]

15. Jangra, A.; Arora, M.K.; Kisku, A.; Sharma, S. The multifaceted role of mangiferin in health and diseases: A review. Adv. Tradit. Med. 2020, 1-25. [CrossRef]

16. Dominicana On-Line. Productive Sectors: Cocoa. Cocoa Production in Dominican Republic. Available online: http://www. dominicanaonline.org/portal/espanol/cpo_cacao.asp (accessed on 24 April 2020).

17. Sangronis, E.; Soto, M.J.; Valero, Y.; Buscema, I. Cascarilla de cacao venezolano como materia prima de infusiones. Arch. Latinoam. Nutr. 2014, 64, 123-130.

18. Cantele, C.; Rojo-Poveda, O.; Bertolino, M.; Ghirardello, D.; Cardenia, V.; Barbosa-Pereira, L.; Zeppa, G. In Vitro Bioaccessibility and Functional Properties of Phenolic Compounds from Enriched Beverages Based on Cocoa Bean Shell. Foods 2020, 9, 715. [CrossRef] [PubMed]

19. Balentić, J.P.; Ačkar, Đ.; Jokić, S.; Jozinović, A.; Babić, J.; Miličević, B.; Šubarić, D.; Pavlović, N. Cocoa Shell: A By-Product with Great Potential for Wide Application. Molecules 2018, 23, 1404. [CrossRef] [PubMed]

20. Pedan, V.; Weber, C.; Do, T.; Fischer, N.; Reich, E.; Rohn, S. HPTLC fingerprint profile analysis of cocoa proanthocyanidins depending on origin and genotype. Food Chem. 2018, 267, 277-287. [CrossRef]

21. Cádiz-Gurrea, M.D.L.L.; Borrás-Linares, I.; Lozano-Sánchez, J.; Joven, J.; Fernández-Arroyo, S.; Segura-Carretero, A. Cocoa and Grape Seed Byproducts as a Source of Antioxidant and Anti-Inflammatory Proanthocyanidins. Int. J. Mol. Sci. 2017, 18, 376. [CrossRef]

22. SOP 04.02.03.21.2019. Procedure for the Collection of Mango Stems Bark in Agricultural Sites; UNEV, Quality Assessment Dept.: Santo Domingo, Dominican Republic, 2019.

23. SOP 04.02.03.22.2019. Procedure for the Collection of Mango Branch Trees in Agricultural Sites; UNEV, Quality Assessment Dept.: Santo Domingo, Dominican Republic, 2019.

24. SOP 04.02.03.23.2019. Procedure for the Collection of Coco Pod Husk in Agricultural Sites; UNEV, Quality Assessment Dept.: Santo Domingo, Dominican Republic, 2019.

25. Sellés, A.J.N.; Rodríguez, M.D.D.; Balseiro, E.R.; Gonzalez, L.N.; Nicolais, V.; Rastrelli, L. Comparison of Major and Trace Element Concentrations in 16 Varieties of Cuban Mango Stem Bark (Mangifera indica L.). J. Agric. Food Chem. 2007, 55, 2176-2181. [CrossRef] [PubMed]

26. Liu, Z.; Jiang, Z.; Fei, B.; Cai, Z. Comparative properties of bamboo and pine pellets. Wood Fiber Sci. 2014, 46, 510-518.

27. Sellés, A.J.N.; Castro, H.T.V.; Agüero, J.; González-González, J.; Naddeo, F.; De Simone, F.; Rastrelli, L. Isolation and Quantitative Analysis of Phenolic Antioxidants, Free Sugars, and Polyols from Mango (Mangifera indica L.) Stem Bark Aqueous Decoction Used in Cuba as a Nutritional Supplement. J. Agric. Food Chem. 2002, 50, 762-766. [CrossRef]

28. Luo, F.; Lv, Q.; Zhao, Y.; Hu, G.; Huang, G.; Zhang, J.; Sun, C.; Li, X.; Chen, K. Quantification and Purification of Mangiferin from Chinese Mango (Mangifera indica L.) Cultivars and Its Protective Effect on Human Umbilical Vein Endothelial Cells under H2O2-induced Stress. Int. J. Mol. Sci. 2012, 13, 11260-11274. [CrossRef]

29. Lerma-Torres, J.M.; Navarro-Ocaña, A.; Calderón-Santoyo, M.; Hernández-Vázquez, L.; Ruiz-Montañez, G.; Ragazzo-Sanchez, J.A. Preparative scale extraction of mangiferin and lupeol from mango (Mangifera indica L.) leaves and bark by different extraction methods. J. Food Sci. Technol. 2019, 56, 4625-4631. [CrossRef]

30. Selles, A.J.N.; Daglia, M.; Rastrelli, L. The potential role of mangiferin in cancer treatment through its immunomodulatory, anti-angiogenic, apoptopic, and gene regulatory effects. BioFactors 2016, 42, 475-491. [CrossRef]

31. Imran, M.; Arshad, M.S.; Butt, M.S.; Kwon, J.-H.; Sultan, M.T. Mangiferin: A natural miracle bioactive compound against lifestyle related disorders. Lipids Health Dis. 2017, 16, 1-17. [CrossRef] [PubMed]

32. Núñez Sellés, A.; Villa, D.G.; Rastrelli, L. Mango polyphenols and its protective effects on diseases associated to oxidative stress Curr. Pharm. Biotechnol. 2015, 16, 272-280. [CrossRef]

33. Núñez Sellés, A.J.; Espaillat Martinez, V.M.; Nuevas Paz, L. HPLC-DAD and HPLC-ESI-MS Analysis of Polyphenol-rich Extracts from Mango (Mangifera indica L.), Tommy Atkins and Haden Varieties, Cultivated in Dominican Republic. Intl. J. Pharm. Chem. 2020, 6, 77-88. [CrossRef]

34. Sellés, A.J.N.; Agüero, J.A.; Paz, L.N. GC-MS analysis of mango stem bark extracts (Mangifera indica L.), Haden variety. Possible contribution of volatile compounds to its health effects. Open Chem. 2021, 19, 27-38. [CrossRef]

35. Sogi, D.; Siddiq, M.; Greiby, I.; Dolan, K.D. Total phenolics, antioxidant activity, and functional properties of 'Tommy Atkins' mango peel and kernel as affected by drying methods. Food Chem. 2013, 141, 2649-2655. [CrossRef] [PubMed] 
36. Dorta, E.; González, M.; Lobo, M.G.; Sanchez-Moreno, C.; de Ancos, B. Screening of phenolic compounds in by-product extracts from mangoes (Mangifera indica L.) by HPLC-ESI-QTOF-MS and multivariate analysis for use as a food ingredient. Food Res. Int. 2014, 57, 51-60. [CrossRef]

37. Ameer, K.; Shahbaz, H.; Kwon, J.-H. Green Extraction Methods for Polyphenols from Plant Matrices and Their Byproducts: A Review. Compr. Rev. Food Sci. Food Saf. 2017, 16, 295-315. [CrossRef] [PubMed]

38. Putnik, P.; Lorenzo, J.M.; Barba, F.J.; Roohinejad, S.; Jambrak, A.R.; Granato, D.; Montesano, D.; Kovačević, D.B. Novel Food Processing and Extraction Technologies of High-Added Value Compounds from Plant Materials. Foods 2018, 7, 106. [CrossRef] [PubMed]

39. Oddoye, E.O.K.; Agyente-Badu, C.K.; Gyedu-Akoto, E. Cocoa and Its By-Products: Identification and Utilization. In Chocolate in Health and Nutrition; Springer Science and Business Media: Berlin, Germany, 2013; pp. 23-37.

40. Velazquez-Araque, L.; Cárdenas, J. A preliminary study of pelletized Ecuadorian cocoa pod husk for its use as a source of renewable energy. In Proceedings of the 20th World Mult-conference on Systems, Cybernetics and Informatics, Orlando, FL, USA, 5-8 July 2016; pp. 29-33.

41. Syamsiro, M.; Saptoadi, H.; Tambunan, B. Experimental Investigation on Combustion of Bio-Pellets from Indonesian Cocoa Pod Husk. Asian J. Appl. Sci. 2011, 4, 712-719. [CrossRef]

42. Tsai, C.-H.; Tsai, W.-T.; Liu, S.-C.; Lin, Y.-Q. Thermochemical characterization of biochar from cocoa pod husk prepared at low pyrolysis temperature. Biomass-Convers. Biorefinery 2017, 8, 237-243. [CrossRef]

43. Campos-Vega, R.; Nieto-Figueroa, K.H.; Oomah, B.D. Cocoa (Theobroma cacao L.) pod husk: Renewable source of bioactive compounds. Trends Food Sci. Technol. 2018, 81, 172-184. [CrossRef]

44. Liu, Y.; Shi, Z.; Maximova, S.N.; Payne, M.J.; Guiltinan, M.J. Proanthocyanidin synthesis in Theobroma cacao: Genes encoding anthocyanidin synthase, anthocyanidin reductase, and leucoanthocyanidin reductase. BMC Plant Biol. 2013, 13, 202. [CrossRef]

45. Valadez-Carmona, L.; Ortiz-Moreno, A.; Ceballos, G.; Mendiola, J.A.; Ibáñez, E. Valorization of cacao pod husk through supercritical fluid extraction of phenolic compounds. J. Supercrit. Fluids 2018, 131, 99-105. [CrossRef]

46. Valadez-Carmona, L.; Plazola-Jacinto, C.P.; Hernández-Ortega, M.; Hernández-Navarro, M.D.; Villarreal, F.; NecoecheaMondragón, H.; Ortiz-Moreno, A.; Ceballos, G. Effects of microwaves, hot air and freeze-drying on the phenolic compounds, antioxidant capacity, enzyme activity and microstructure of cacao pod husks (Theobroma cacao L.). Innov. Food Sci. Emerg. Technol. 2017, 41, 378-386. [CrossRef]

47. Alves, T.V.G.; da Costa, R.S.; Aliakbarian, B.; Casazza, A.A.; Perego, P.; Arruda, M.S.P.; Júnior, J.O.C.S.; Converti, A.; Costa, R.M.R. Bioactive compounds and antioxidant potential for polyphenol-rich cocoa extract obtained by agroindustrial residue. Nat. Prod. Res. 2017, 33, 589-592. [CrossRef] [PubMed]

48. Cádiz-Gurrea, M.D.L.L.; Lozano-Sanchez, J.; Contreras, M.D.M.; Legeai-Mallet, L.; Fernández-Arroyo, S.; Carretero, A.S. Isolation, comprehensive characterization and antioxidant activities of Theobroma cacao extract. J. Funct. Foods 2014, 10, 485-498. [CrossRef]

49. Lu, F.; Garcia, J.R.; Van Damme, I.; Westwood, N.J.; Shaw, L.; Robinson, J.S.; Warren, G.; Chatzifragkou, A.; Mason, S.M.; Gomez, L.; et al. Valorisation strategies for cocoa pod husk and its fractions. Curr. Opin. Green Sustain. Chem. 2018, 14, 80-88. [CrossRef]

50. Hernández-Hernández, C.; Viera-Alcaide, I.; Sillero, A.M.M.; Fernandez-Bolaños, J.; Rodríguez-Gutiérrez, G. Bioactive compounds in Mexican genotypes of cocoa cotyledon and husk. Food Chem. 2018, 240, 831-839. [CrossRef]

51. Rojo-Poveda, O.; Barbosa-Pereira, L.; Zeppa, G.; Stévigny, C. Cocoa Bean Shell—A By-Product with Nutritional Properties and Biofunctional Potential. Nutrients 2020, 12, 1123. [CrossRef] [PubMed]

52. Mazzutti, S.; Rodrigues, L.G.G.; Mezzomo, N.; Venturi, V.; Ferreira, S.R.S. Integrated green-based processes using supercritical $\mathrm{CO} 2$ and pressurized ethanol applied to recover antioxidant compouds from cocoa (Theobroma cacao) bean hulls. J. Supercrit. Fluids 2018, 135, 52-59. [CrossRef]

53. Barbosa-Pereira, L.; Guglielmetti, A.; Zeppa, G. Pulsed Electric Field Assisted Extraction of Bioactive Compounds from Cocoa Bean Shell and Coffee Silverskin. Food Bioprocess Technol. 2018, 11, 818-835. [CrossRef]

54. Yusof, A.H.M.; Gani, S.S.A.; Zaidan, U.H.; Halmi, M.I.E.; Zainudin, B.H. Optimization of an Ultrasound-Assisted Extraction Condition for Flavonoid Compounds from Cocoa Shells (Theobroma cacao) Using Response Surface Methodology. Molecules 2019, 24, 711. [CrossRef] [PubMed]

55. Sun-Waterhouse, D.; Waterhouse, G.I.; You, L.; Zhang, J.; Liu, Y.; Ma, L.; Dong, Y. Transforming insect biomass into consumer wellness foods: A review. Food Res. Internat. 2016, 89, 129-151. [CrossRef] [PubMed]

56. Padam, B.S.; Tin, H.S.; Chye, F.Y.; Abdullah, M.I. Banana by-products: An under-utilized renewable food biomass with great potential. J. Food Sci. Technol. 2012, 51, 3527-3545. [CrossRef]

57. Savadori, L.; Savio, S.; Nicotra, E.; Rumiati, R.; Finucane, M.; Slovic, P. Expert and public perception of risk from biotechnology. Risk Anal. Int. J. 2004, 24, 1289-1299. [CrossRef]

58. Siegrist, M. The Influence of Trust and Perceptions of Risks and Benefits on the Acceptance of Gene Technology. Risk Anal. 2000, 20, 195-204. [CrossRef] [PubMed]

59. Curtis, K.R.; McCluskey, J.J.; Wahl, T.I. Consumer Acceptance of Genetically Modified Food Products in the Developing World. Agro BioForum 2004, 7, 70-75.

60. Silano, V.; Coppens, P.; Larrañaga-Guetaria, A.; Minghetti, P.; Roth-Ehrang, R. Regulations applicable to plant food supplements and related products in the European Union. Food Funct. 2011, 2, 710-719. [CrossRef] [PubMed]

61. Available online: https://www.cne.gob.do/wp-content/uploads/2015/11/potencial-solar.pdf (accessed on 13 April 2020). 
62. Available online: https://www.pelletheat.org/assets/docs/2018/2018_PFI_Standard\%20Specification.pdf (accessed on 23 February 2020).

63. Feldsine, P.; Abeyta, C.; Andrews, W.H. AOAC INTERNATIONAL Methods Committee Guidelines for Validation of Qualitative and Quantitative Food Microbiological Official Methods of Analysis. J. AOAC Int. 2002, 85, 1187-1200. [CrossRef] [PubMed]

64. Vo, T.H.T.; Nguyen, T.D.; Nguyen, Q.H.; Ushakova, N.A. Extraction of Mangiferin from the Leaves of the Mango Tree Mangifera indica and Evaluation of its Biological Activity in Terms of Blockade of $\alpha$-glucosidase. Pharm. Chem. J. 2017, 51, 806-810. [CrossRef] 